\title{
GIS Based Assessment of Flood Risk and Vulnerability of Communities in the Benue Floodplains, Adamawa State, Nigeria
}

\author{
Ikusemoran Mayomi ${ }^{1}$, Anthony Dami ${ }^{1} \&$ Maryah, U. M ${ }^{1,2}$ \\ ${ }^{1}$ Department of Geography, University of Maiduguri, Nigeria \\ ${ }^{2}$ Center for Disaster Risk, Management and Development Studies, University of Maiduguri, Nigeria \\ Correspondence: Ikusemoran Mayomi, Remote Sensing and GIS Unit, Department of Geography, University of \\ Maiduguri, Nigeria. Tel: 234-806-365-7395. Email: princemayomi@yahoo.com
}

Received: July 19, 2013 Accepted: October 10, 2013 Online Published: November 22, 2013

doi:10.5539/jgg.v5n4p148

URL: http://dx.doi.org/10.5539/jgg.v5n4p148

\begin{abstract}
The focus of this study is to assess the 2012 floods incidence that swept the communities along the coastal areas of Nigeria as well as those along the valleys of the major rivers in the country. It was observed in the study that the floods at the valleys and downstream of River Benue were seriously devastating following the release of water from the Lagdo dam that was located at the upstream of River Benue in the Republic of Cameroon. The method of data collection employed in this study is the application of Geo-information techniques which involves the use of Global Positioning System (GPS) to capture the coordinates of 120 communities which cut across the seven LGAs located along the valleys of River Benue in Adamawa State. These communities were linked to a generated digital map of River Benue valley using ArcGIS software to assess each of the communities for flood vulnerability. Vulnerability was classified into four: highly vulnerable, vulnerable, marginally vulnerable and not vulnerable. The major findings revealed that all the 120 communities in the area were described as vulnerable to flood, that is, they are either highly vulnerable, vulnerable or marginally vulnerable. 29 communities representing 32.5\% were located on highly vulnerable areas, 35 communities (representing 29.17\%) were found to be located within the Benue Basin but outside the buffer zones which are classified as vulnerable areas, while the remaining 46 communities (38.33\%) were located on the plains which are classified as marginally vulnerable areas. Escape routes and good sites for refugee camps during floods were also identified while database creation and analysis for flood vulnerability were also developed. It is therefore, recommended that all the settlements that were highly vulnerable be relocated to higher grounds to prevent future occurrence, while the communities that are located within the Benue Basin but outside the buffer zones should employ the use of GIS tool for effective planning and proper early warning systems.
\end{abstract}

Keywords: digital elevation modeling (DEM), flood vulnerability, GIS, river benue, lagdo dam

\section{Introduction}

\subsection{Introduction}

In 2012, heavy rains and the release of water from Lagdo dam upstream River Benue in the Republic of Cameroon resulted into serious floods in all the states (Adamawa, Taraba, Benue, Nassarawa, Plateau and Kogi) that are located along the downstream of River Benue in Nigeria. Konwea (2012) described the flood as the worst floods Nigeria has seen in at least half a century, which has led to the deaths of hundreds of Nigerians, displaced over a million people, and destruction of hundreds of thousands of hectares of farmland. Huge swathes of the country have been affected, particularly in central and south-eastern regions, with houses, bridges and roads devastated. Many refugee camps were overcrowded with little or no aid materials, certain areas and cities now suffer from shortages of food staples, some predict the loss of farmlands will endanger Nigeria's food security in the longer-term, while others fear waterborne diseases could spread to epidemic levels.

Flood has been major threatening natural disaster in many parts of the world. For instance, according to Vanneuville et al. (2011), the coastal area of Bangladesh was flooded after a cyclone in November 1970 which killed 500,000 people and making it one of the worst natural disasters of the 20th century. Moreover, deadly flooding that killed more than 300 people in Bangladesh in 1998 submerging more than half of the country; many roads became impassable, leaving millions of people stranded or homeless, while relief officials said food 
shortages and disease would likely cause more deaths. African countries were also not left out as South Africa was reported to have been affected by floods caused by a record-breaking five-day rainstorm in 2009 killed at least 400 people in Natal Province and left at least 55,000 homeless. Damage was estimated at $\$ 500$ million, including roads, railroad lines, and 14 major highway bridges that were swept away.

The 2012 flood in Nigeria was widely reported to have resulted solely from the release of water from Lagdo dam by the Cameroon (Adamawa State Government, 2012). The effect of the Lagdo dam spillway on the downstream has long been generally believed by the inhabitants as the major cause of Adamawa floods. For instance, Galtima and Bashir (2002) in Nwilo et al. (2012), conducted a study on the people's perception on the causes of flood in Adamawa floodplains, revealed that $58.3 \%$ supported the release of the Lagdo dam water as the main cause, while $25 \%$ supported the effect of rainfall intensity. However the 2012 Adamawa flood was believed to have resulted from the combination of Lagdo dam effect and rainfall intensity as evidenced by the satellite images in Plates $1 \mathrm{a}$ and $1 \mathrm{~b}$ which show the narrow river valleys of Niger and Benue in Nigeria in October 2008 and the wide expansion of the river valleys in the same period in 2012. According to Adamawa State Government (2012), it was this excessive water due to heavy rains that forced the Cameroonian government to open the spillways of Lagdo dam having sent warnings to Nigeria for the release of the water. Moreover, through the Flood Early Warning Centre, Nigeria's Ministry of Environment (2012) issued a forecast of heavy rainfall in mid-September and warned of potential flooding in some parts of the country (Adamawa State inclusive).

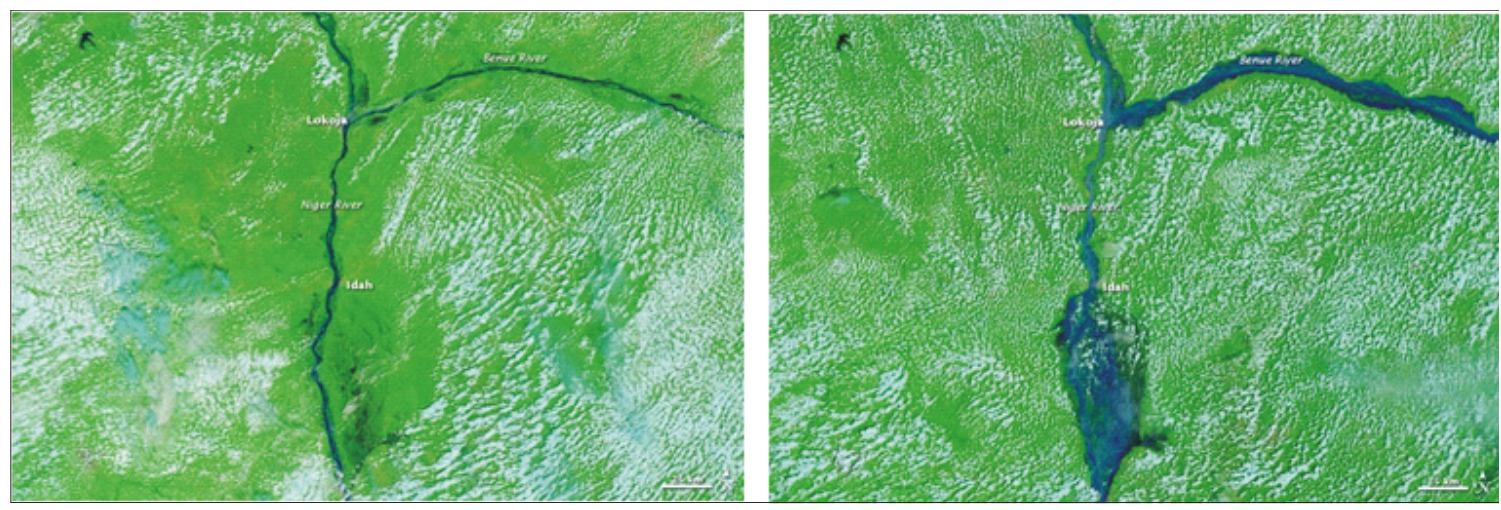

Figure 1a. Satellite image of Niger-Benue (Oct/20/2008) Figure 1b. Satellite image of Niger-Benue (Oct/13/2012)

Source: NASA, (2012).

Though, there has not been any report to ascertain the state that was most affected by the flood, but one thing that is certain is that all the states in the Benue basin were badly swept by the flood. Adamawa state being one of the affected states was reported to be among the worst hit States as evidenced from Figure 2 and according to the classification of the flood vulnerability of the States into categories by the president of the Federal Republic of Nigeria. The (flood affected) States were categorized into four: in category A (the worst-hit states) are eight states consisting of Adamawa, Oyo, Kogi, Anambra, Bayelsa, Delta, Benue, and Plateau. Hence, having discovered the State to be one of the worst flood-hit States in the country, the need to study flood vulnerability in Adamawa State.
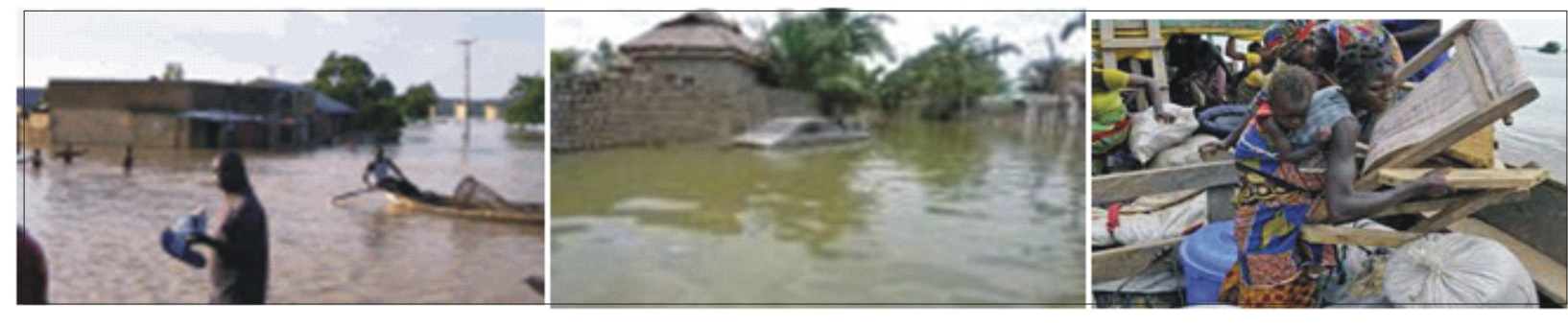

Figure 2. Situations during the 2012 flood in Adamawa State

Source: The Guardian Sept. 19 ${ }^{\text {th }}, 2012$. 


\subsection{Statement of the Problem}

Since the flood occurrence, the Federal Government through the National Emergency Management Authority (NEMA) is planning resettlement of the affected communities in all the states to saver places. However, the fear of the people is that the selection of the communities that are supposed to be compensated or relocated may also suffer the same problems that arose from the disbursements of funds to the flood victims shortly after the floods (Adamawa State Government, 2012). The data, on which the disbursements of the funds were based, were manually generated and analyzed. For instance, among the envisaged problems was that the names of the communities that need resettlement may disappear, while some villages that are far from being affected by the flood may be recommended for resettlements for the sake of the financial benefits. Hence, to avoid these problems, there is the need for automated means of data generation and decision making so as to bring a reliable and lasting solution to the aforementioned problems. Geographic Information System (GIS) has the capability of automatic data generation and decision making ability on spatial and non-spatial referenced features. GIS is defined as "a system of computer hardware, software and procedures designed to support the capture, management, manipulation, analysis, modularity and display of spatially referenced data for solving complex planning and management problems" (Nyerges, 1992).

\subsection{Significance of the Study}

Whenever disasters with great magnitudes occur in a country, efforts are usually made to prevent future occurrences where possible, or at least minimize the impacts through various preventive programs and mechanisms. Since the flood incidence, suggestions have been made by the general public to the government to relocate some of the settlements that are so close to River Benue as well as those that are vulnerable to the floods (Adamawa State Government, 2012). Ever before now, and in similar situations in Nigeria, manual methods such as land survey, field studies, administration of questionnaires and interview were the common methods of data acquisition and on which crucial decisions on such matters were made (Ikusemoran, 2000). Most of these decisions were discovered not good enough to give permanent solutions to such problems because most at times, the failures of these decisions stem from the problems associated with the data on which such decisions were based. Most manually generated data are known to be subjected to inaccuracies which may result from inadequate capital and use of inexperience personnel for data generation. Human influence is another major associated problem as parochial factors are put in place by those who generate the data as well as those who make the decisions (Ikusemoran, 2000). Hence, there is the need for the use of automated technology such as remotely sensed data and GIS techniques for data generation and analysis on which subsequent decisions that are free from human manipulations and which can be considered reliable and subjected to future update are required for flood vulnerability assessment in Nigeria. Therefore, GIS can be used to identify and delineate all the communities along the Benue Basin in Adamawa State that are vulnerable to floods and as such need resettlement, as well as generating a database with the capability of decision making on the settlement with minimal human interventions.

GIS techniques have been successfully applied all over the world for flood monitoring, vulnerability, management and control. For instance, Pieter et al. (2010) applied GIS for flood risk management in Flanders: a region in Belgium where a risk based technology was created to quantitatively assess flood risk based in hydrologic models, landuse information and socio-economic data. The method was said to have been implemented in a specifically designed GIS-based flood risk assessment called LATIS. LATIS was assessed to have the possibility to perform risk analysis quickly and effectively. In Adamawa State floodplains, Nwilo et al. (2012) adopted Remote Sensing and Cellular Automated Evaluation Slope and River (CAESAR) to determine inundation level and assessment vulnerability of settlements in Adamawa State. The results showed that, an average of 134 settlements were of high risk. The aim of this study therefore, is to develop geospatial assessment of flood risk and also to identify and classify the vulnerability of each community along the floodplains in the Benue Basin of Adamawa State.

\section{The Study Area}

Adamawa State of today was carved out from the defunct Gongola State on 27th August, 1991. Before then, Adamawa was a province of the Northern region of Nigeria. Adamawa State is bounded in the North by Borno state, West by the Republic of Cameroon, South and South-West by Taraba State and Central West by Gombe State (Figure 3). 


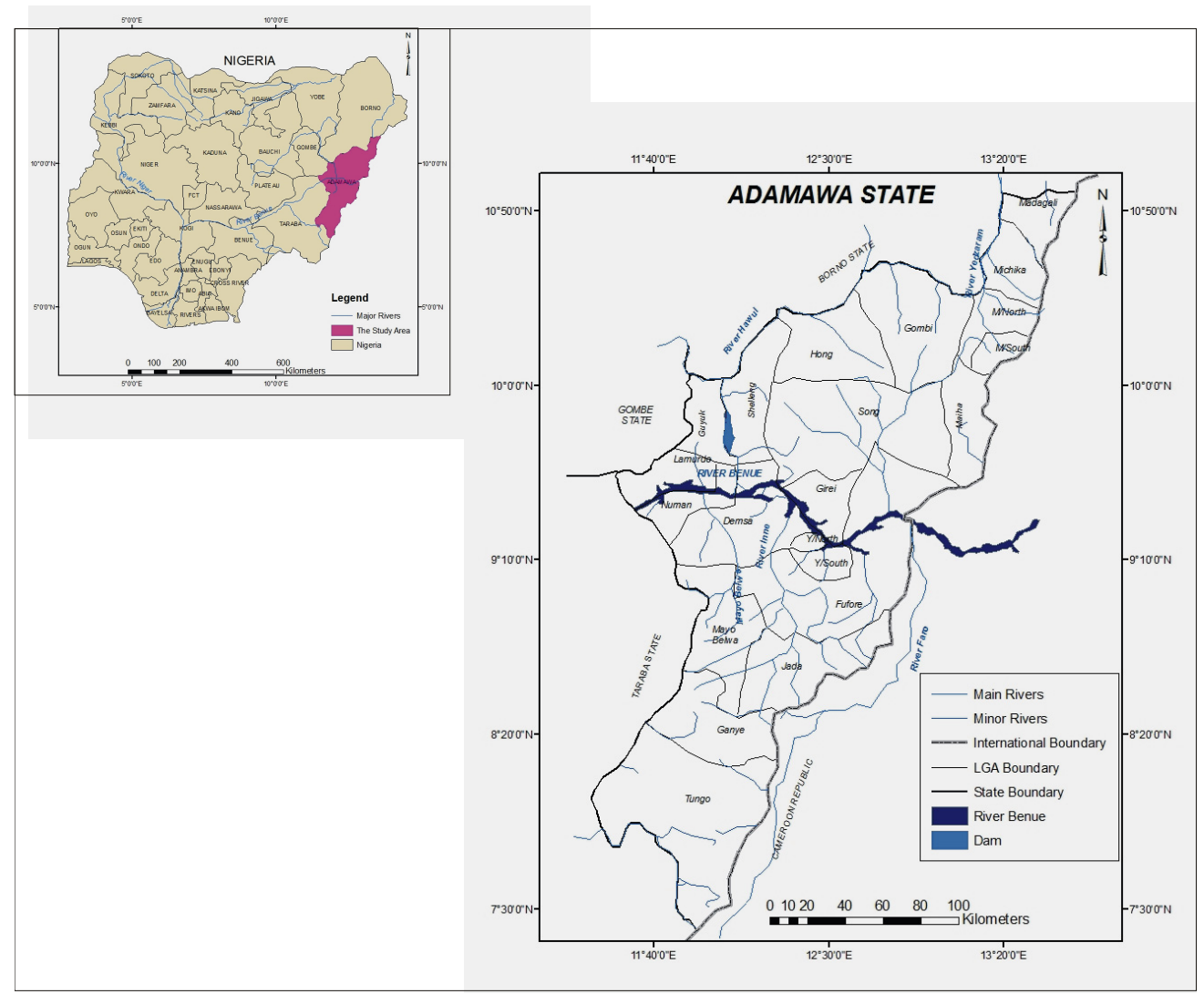

Figure 3. The study area

According to Tukur (1999), the landforms of Adamawa State are grouped into: (i) the valleys and troughs (with heights between 100 and less than $311 \mathrm{~m}$ (Figure 4)), the lowlands (with heights between 311 and less than $470 \mathrm{~m}$ (Figure 4)), the uplands plains (between 470 and less than $683 \mathrm{~m}$ (Figure 4)), and the mountain ranges (with the heights between 683 and $1740 \mathrm{~m}$ (Figure 4)). Opeloye and Dio (1999) described the geology of Adamawa State to encompass parts of an ancient craton that was tectonically active in geologic past. A rift was created from one of such tectonics in the cretaceous and was filled with series of sedimentary deposits. This rift divides the State into almost two equal halves (Figure 4) resulting into four main classes of rocks. The first is the alluvial or sedimentary deposit within the rift represented by the light blue colour in Figure 4 . The second rock type is the cretaceous continental deposit which is shown with deep blue colour in Figure 4. Next is the hard crystalline cratonic basements shown with yellow colour (Figure 4). The red colour represents the tertiary/quaternary deposit. 


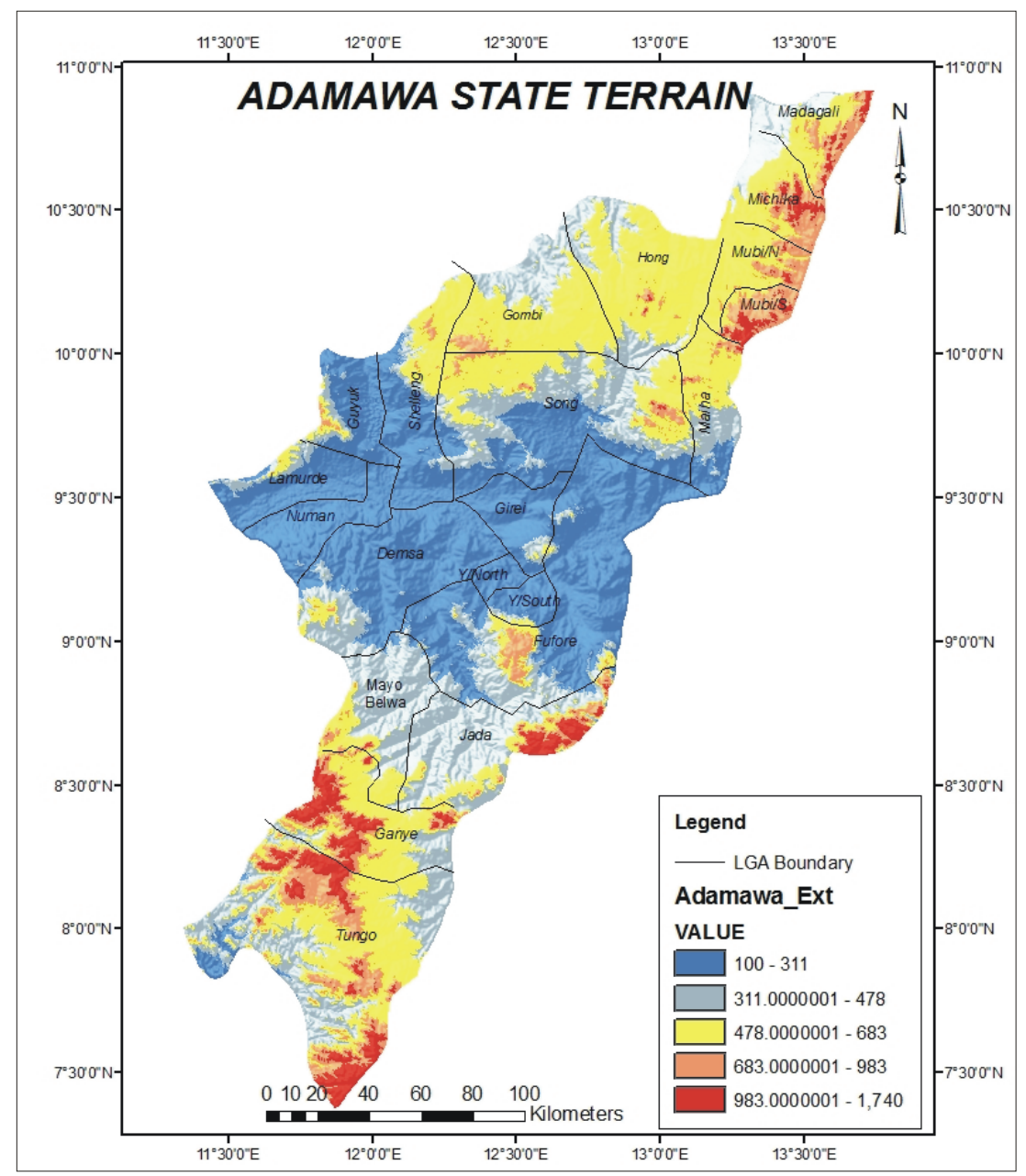

Figure 4. The relief of Adamawa State

On the drainage of Adamawa State, Adebayo and Umar (1999) reported that the State is dominated by three main drainage systems-the Benue, the Yedzaram and the Taraba. The Benue which is the major river in the state rises from the highlands of Cameroon and flows south-wards with major tributaries such as Rivers Gongola, Belwa, Inne, Kilange, Loko and Faro (Figure 1). They also observed that the Benue and its tributaries are normally flooded during the rainy season and become dry with sandy flat beds during the dry season. River Yedzaram takes its source from the Hudu hills east of Mubi and flows northwards and eventually drains into Lake Chad. The Taraba rises from Jombi Mountains in the extreme south and flows westwards to join River Benue in Taraba State. Adebayo (1999), on the climate of Adamawa State, reported that the mean annual rainfall pattern shows that the amounts range from $700 \mathrm{~mm}$ in the north-west to $1600 \mathrm{~mm}$ in the southern part. The mean on-set dates vary from 10th April in the South to 20th May in the Northern part, while normal cessation dates range from 16th September in the North to 6th November in the extreme South, while the mean length of rainy season ranges from 120 to 210 days in the state.

According to the Federal Official Gazette of Nigeria (2009), the 2006 Population Census results put the following ten LGAs in Adamawa State as having more than 160,000 people: Fufore $(209,460)$, Yola North $(199,674)$, Yola South $(196,197)$, Song $(195,188)$, Demsa $(178,407)$, Guyuk $(176,505)$, Ganye $(169,948)$, Hong $(169,183)$, Jada $(168,445)$. From these LGAs only Hong and Ganye LGAs are not located along the Benue basin. Hence, the Benue Basin of the State can be said to be more in population than the other parts of the state.

\section{Materials and Methods}

The following materials and data were acquired for this study: Digital Elevation Dataset from Shuttle Radar Topographical Mission (SRTM). The spatial locations of some communities were also acquired by the use of Germin 72 GPS, Atlas Map from where political boundaries and roads were digitized. Field work with GPS and notebook were also used to acquire and record the coordinates of the communities respectively. 


\subsection{Creation of Digital Elevation Models (DEM) of Adamawa State}

Since risk zone assessment of floods largely depends on proximity to waterbody and the terrain of the area, it is therefore necessary to generate the terrain map of the area which was achieved through the DEM creation module of ArcGIS software, using Digital Elevation Dataset from Shuttle Radar Topographical Mission (SRTM), which automatically shows the topography and the heights of each components of the terrain as well as the proximity to the waterbody.

\subsection{Extraction of the floodplains LGAs along the Benue Plains in Adamawa State}

Having identified the LGAs that lie along the River Benue plains, the next task is the extraction of all the LGAs within the plains from the entire Adamawa state map by the use of the extraction module of ArcGIS so as to have the specific area of interest instead of working on the whole Adamawa State.

\subsection{Creation of Buffer Zones along River Benue on the Extracted Map}

In this paper, 120 communities located either on Benue basin, river banks, Benue plains or upland regions were selected for flood vulnerability assessment. The specific locations of all the settlements were derived by using GPS to obtain the coordinates of each of the locations of the 120 selected settlements along River Benue in Adamawa State. Flood intensity all over the world depends on the proximity or the closeness of any location from the main causal waterbody, hence, the closer any community is to the main River Benue, the higher the risk of been flooded, though, depending on the topography of the area. For instance, the Benue Basin (located within the Benue Plain and along River Benue) is more vulnerable to flood than the other areas outside the Benue Basin (Figure 5) Therefore, the actual locations of each of the communities were linked to the extracted map as shown in Figure $6.3 \mathrm{~km}$ buffer along River Benue was used in this paper and which was based on the average furthest distance of all the communities that were reported to be seriously affected during the flood. The output map of the locations of each of the identified settlements and the $3 \mathrm{kms}$ buffer zone is presented in Figure 6.

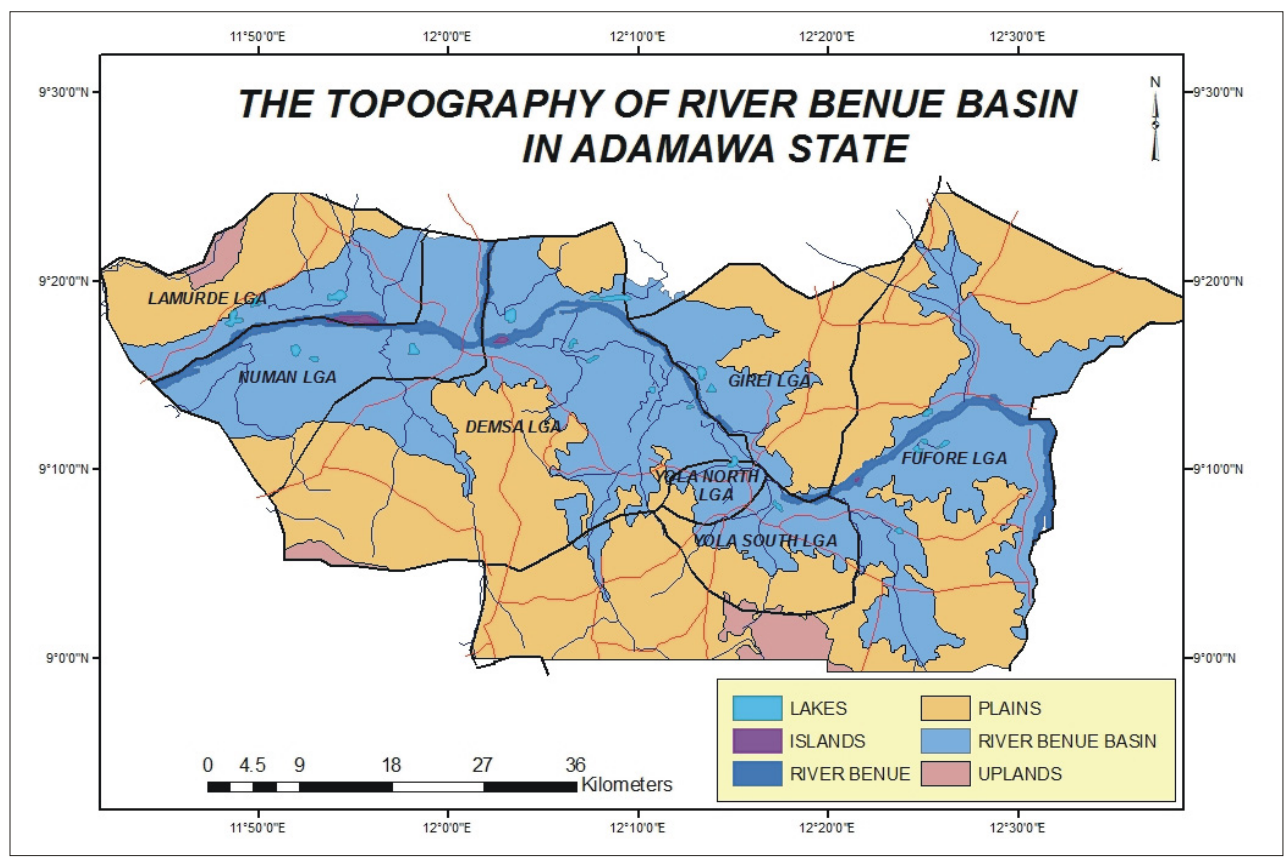

Figure 5. Topography of river benue basin, Adamawa State 


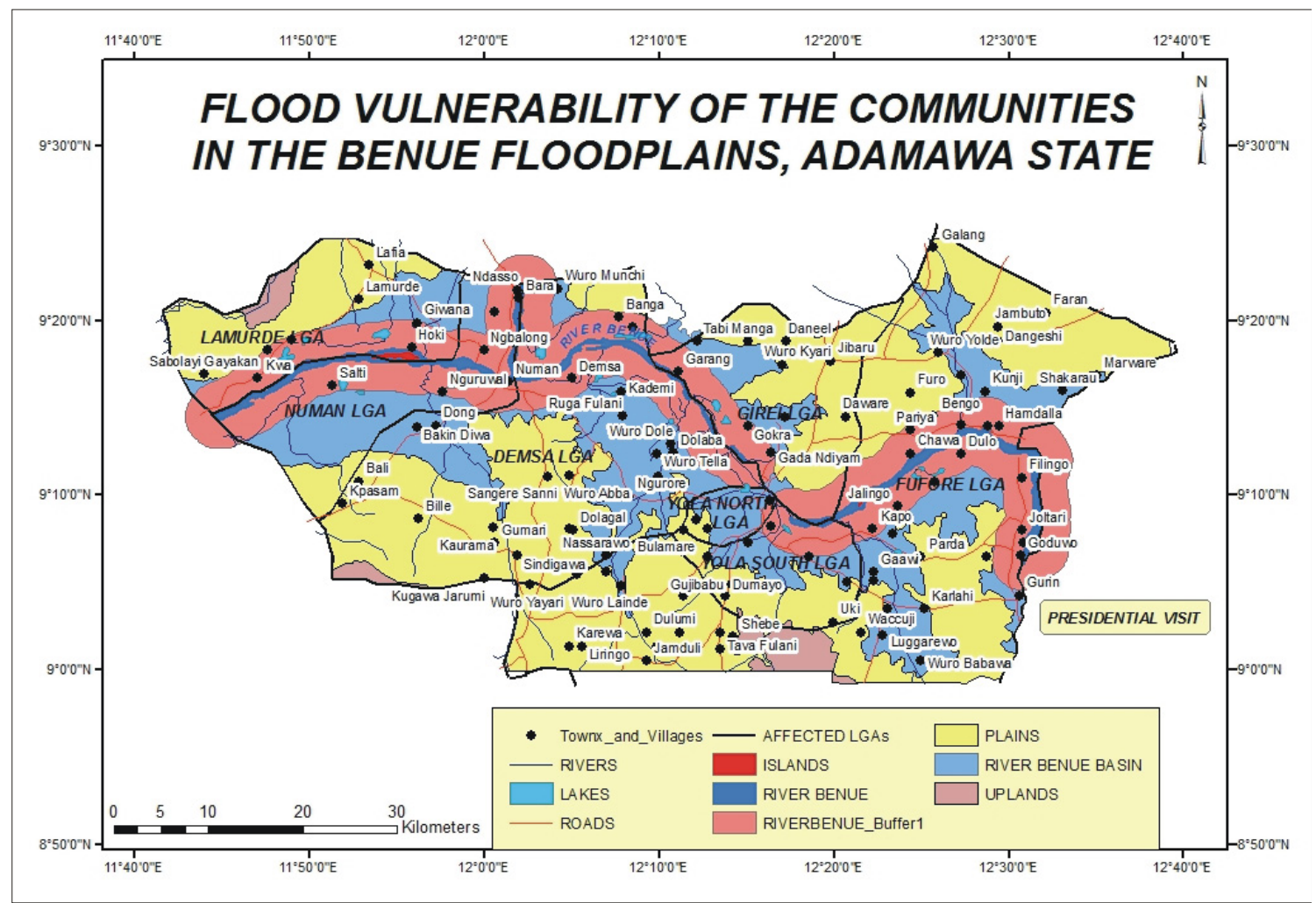

Figure 6. Flood vulnerability of some communities in Adamawa State floodplains

\subsection{Flood Vulnerability Mapping}

Flood vulnerability map was generated from the extracted DEM map with the $3 \mathrm{kms}$ buffer zone showing all the 120 settlements. Flood vulnerability of the communities based on their locations was classified into the following:

(i) Highly Vulnerable: All the communities within the buffer zone;

(ii) Vulnerable: All the communities located in the Benue Basin;

(iii) Marginally vulnerable: All the communities located in the Benue Plains;

(iv) Not Vulnerable: All the communities located in the upland areas.

\subsection{Identification of Escape Routes and Shelter Sites in the Flood Prone Areas}

Usually in any disaster (natural or human), plans are always put in place to evacuate the trapped victims from the danger zones to saver areas. However, one of the challenges that are always faced in this situation is the inability to know the escape routes in such areas, bearing in mind that in most cases, the rescue team may not have prior knowledge about the terrain of the area. Therefore, the rescue teams especially in the developed countries rely heavily on remotely sensed data and GIS technology to identify the escape routes during disasters. Hence, topographical maps, aerial photographs and satellite images are common data sources through which escape routes can be identified. In this paper, existing roads were digitized and overlain on the processed DEM maps (Figure 7) to see the routes through which the victims can escape or be evacuated during floods. 


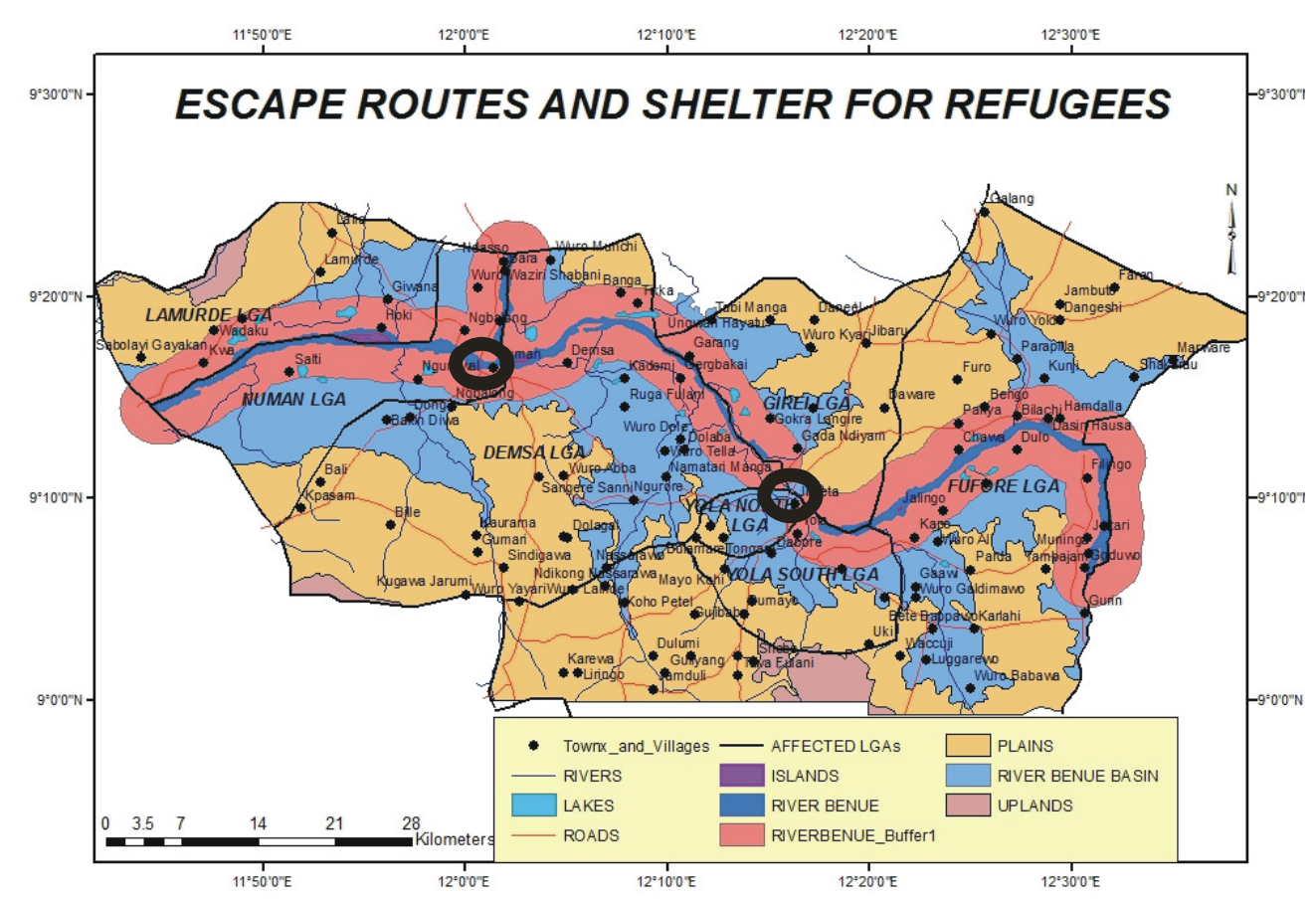

Figure 7. Flood vulnerability of some communities in Adamawa State floodplains

\subsection{Development of Geo-database and Spatial Query for Decision Making}

The creation of DEM map and the generation of buffer zones for risk assessment have little or no values if the maps and the attribute information presented in a tabular form cannot be digitally analyzed. Database was created, where the field contains the name of each community, the coordinates, LGA and locations of each of the 120 communities, while each of the communities has their records.

\section{Data Presentation}

\subsection{Adamawa State DEM and the Extracted LGAs}

Figures $8 \mathrm{a}$ and $8 \mathrm{~b}$ show the DEM and the contour of Adamawa State respectively. Figure $8 \mathrm{~b}$ is the contour of Adamawa State which also shows the conspicuous River Benue Basin that almost divides the State into two equal halves. Figure 8a revealed that ten out of the twenty one LGAs in Adamawa State are located along the Benue plains. Hence, only the ten LGAs (Demsa, Fufore, Girei, Guyuk, Lamurde, Numan, Shelleng, Song, Yola North and Yola South LGAs) are liable to flood especially due to release of water from Lagdo dam in Cameroon.

Map modeling entails the spatial analysis of some natural and manmade features. In flood risk modeling, the locations of the imminent causal feature (River Benue in this paper) as well as other contributing features such as the topography, tributaries and creation of buffer zones are very important. The knowledge of the topography of a place gives the understanding of the direction of flow of rivers, possible areas that are liable to flood and assessment of flood risk regions as shown in Figure 5. In this paper, Guyuk and Shelleng LGAs lie along the basin of River Gongola (Figure 2), therefore, floods in these two LGAs would definitely be more of the effect of River Gongola than that of floods of River Benue. Hence, the two LGAs were excluded from the ten LGAs that are located in the Benue plains. Song LGA too has only very sall flood affected portion in the southern part in the Benue plains; hence, the LG was also excluded from the study, making the remaining flood affected LGAs to be seven as shown in Figure 5. 


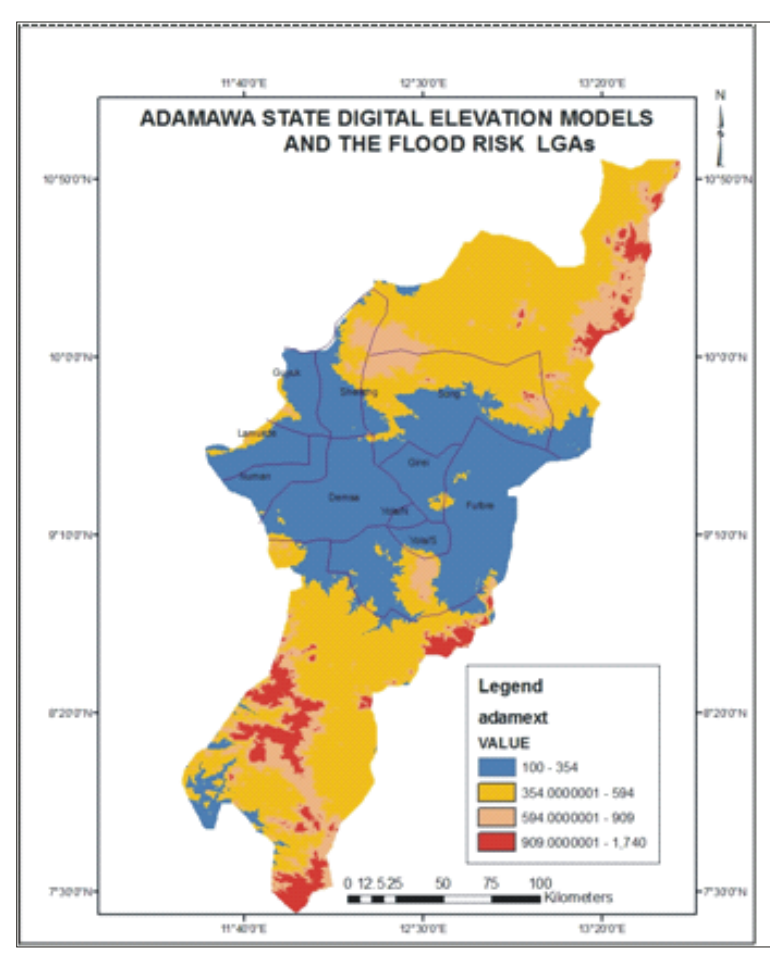

Figure 8a. Digital elevation models of Adamawa

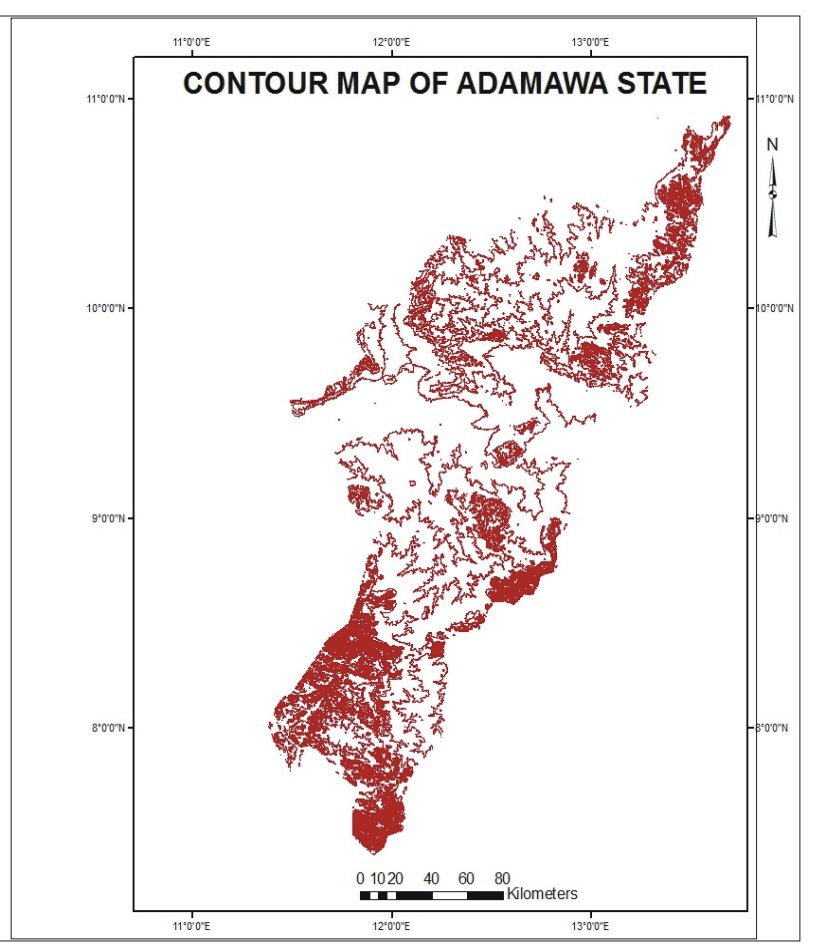

Figure 8b. Contour of Adamawa State

Figure 6 and Table 1 revealed that, out of the one hundred and twenty (120) communities that were sampled for flood vulnerability, 12 were found to be located on river banks, while 27 other ones were found within the buffer zone. Therefore, collectively, the 39 communities representing $32.5 \%$, were said to be highly vulnerable to floods. All the settlements that were highly vulnerable are suggested to be urgently relocated to higher grounds to prevent future occurrence. 35 communities (representing 29.17\%) were found to be located within the Benue Basin but outside the buffer zones. These 35 communities are also liable to flood but with less vulnerability than those on the banks of the River Benue and those within the buffer zone. The communities in this zone were suggested to be subjected to proper early warning, while effective town planning measures should be put in place in those communities. 46 communities $(38.33 \%$ ) were located on the plains (Figure 9 and Table 1) which were classified as less vulnerable than the communities in the Benue Basin. Therefore, all the 120 communities in the study were discovered to be either highly vulnerable, vulnerable or marginally vulnerable. However, $61.67 \%$ of the communities were classified as highly vulnerable, while the remaining $38.33 \%$ were classified as vulnerable or marginally vulnerable.

Table 1 also reveals that Fufore and Numan LGAs have more settlements that are highly vulnerable to floods than the other LGAs. Numan LGA in general and Numan town in particular was seriously affected because of its geographic location, that is, at the confluence of River Gongola to River Benue (Figure 6). This made the town to suffer "double" impacts of floods, that is, floods from River Benue and that of River Gongola. River Gongola has two dams at its upstream; Dadin Kowa dam in Gombe State and Kiri Dam in Adamawa State. These two dams also released water through their spillways during the floods which made Numan to be heavily swept by the floods (Figure 1). Fufore is the boundary LGA between Nigeria and Cameroon, hence the LGA is expected to be more affected by the flood since the released water from the Cameroonian Lagdo dam reaches them first before the other LGAs at the downstream. It was because of the heavy impacts of the flood in this LGA that made the LG the host of the President of the Federal Republic of Nigeria when he paid condolence visit to the bereaved victims as well as the refugees The president visited a village called Gurin, one of the largest refugee camp (marked presidential visit in Figure 6) during his inspection tour of the flood ravaged state.

The seven LGAs which were identified in this study as the most affected LGAs in Adamawa as shown in Table 1, coincides with the seven LGAs that were also listed by the Adamawa State Government as the most affected LGAs. The affected Local Governments are Yola North, Yola South, Girei, Fufore, Numan, Lamurde, and Demsa, as reported by the Adamawa State Government (2012). Moreover, President Goodluck Jonathan, paid a whistle stop inspection visit to the flood ravaged plains of Adamawa State at a refugee camp in Gurin, Fufore Local 
Government Area. Gurin settlement which is marked presidential visit in Figure 6, is though, located on the Benue Basin but fall outside the buffer zone, hence its suitability for refugee camp because of its close proximity to the flood ravaged areas and it's less vulnerability to floods.

Table 1. Flood Vulnerability of some communities in the Adamawa State Floodplains

\begin{tabular}{|c|c|c|c|c|c|}
\hline & \multicolumn{5}{|c|}{ Vulnerability Of The Communities In The Adamawa State Floodplains } \\
\hline & Highly Vulnerable & & Vulnerable & Marginally Vulnerable & Not Vulnerable \\
\hline & River Banks & Buffer Zones & Benue Basin & Plains & Uplands \\
\hline Demsa & Nill & $\begin{array}{l}\text { Demsa, } \\
\text { Banga, } \\
\text { Tikka, } \\
\text { Gergbakai }\end{array}$ & $\begin{array}{l}\text { Bakin Diwa, } \\
\text { Dolaba, } \\
\text { Dong, Kademi, } \\
\text { Namatari Manga, } \\
\text { Nassarawo, } \\
\text { Ngbalong, } \\
\text { Ngurore, Ruga } \\
\text { Fulani, } \\
\text { Wuro Dole, Wuro } \\
\text { Munchi, Wuro } \\
\text { Tella }\end{array}$ & $\begin{array}{l}\text { Bali, Bille, Dolagai, } \\
\text { Garigashi Ndikang, } \\
\text { Gumari, Jauro Yahaya, } \\
\text { Kaurama, } \\
\text { Kpasam, Kukawa Jarumi, } \\
\text { Sangere Sanni, Sindigawa, } \\
\text { Wuro Abba }\end{array}$ & Nill \\
\hline Fufore & $\begin{array}{l}\text { Billachi, Chawa, } \\
\text { Chikito, Dasin } \\
\text { Hausa, Goduwo, } \\
\text { And Muninga }\end{array}$ & $\begin{array}{l}\text { Bengo, Bodare, } \\
\text { Dulo, } \\
\text { Filingo, } \\
\text { Hamdalla, } \\
\text { Jalingo, Joltari, } \\
\text { Kapo And Pariya }\end{array}$ & $\begin{array}{l}\text { Bette Bapawo, } \\
\text { Gaawi, } \\
\text { Karlahi, Kunji, } \\
\text { Luggarewo, } \\
\text { Marmare, } \\
\text { Ndikong } \\
\text { Nassarawa, } \\
\text { Parapilla, } \\
\text { Shakarau, } \\
\text { Wuro Ali, Wuro } \\
\text { Babawa, Wuro } \\
\text { Galdimawo, Wuro } \\
\text { Lainde, Gurin } \\
\end{array}$ & $\begin{array}{l}\text { Parda, Tambajam, } \\
\text { Faran, Jambutu, Wuro Yolde, } \\
\text { Dangeshi, Furo, Waccuji, } \\
\text { Wuro Yayari, Koho } \\
\text { Patel, Karewa, Liringo, } \\
\text { Jamduli, } \\
\text { Guliyang, Tava Fulani, Jilli } \\
\text { Mbalare, Shebe, } \\
\text { Dulumi, Lainde Jallo }\end{array}$ & Nill \\
\hline Girei & Girei & $\begin{array}{l}\text { Gada Ndiyam, } \\
\text { Gokra }\end{array}$ & $\begin{array}{lr}\text { Langire, } & \text { Tabi } \\
\text { Manga, } & \text { Wuro } \\
\text { Kyari } & \\
\end{array}$ & $\begin{array}{l}\text { Daneel, Daware, Jibaru, } \\
\text { Ungwan Hayatu }\end{array}$ & Nill \\
\hline Lamurde & Hoki & $\begin{array}{l}\text { Giwana, Kwa, } \\
\text { Tigno } \\
\text { Wadatu }\end{array}$ & Nill & $\begin{array}{l}\text { Lafia, Lamurde, } \\
\text { Sabolayi Gayakam, }\end{array}$ & Nill \\
\hline Numan & $\begin{array}{l}\text { Bara, Kapalakan, } \\
\text { Ndasso, Numan }\end{array}$ & $\begin{array}{l}\text { Ngbalang, } \\
\text { Nguruwal, Salti, } \\
\text { Wuro Waziri } \\
\text { Shabani } \\
\end{array}$ & Nill & Nill & Nill \\
\hline Yola North & Nill 12 & Jimeta 27 & Nill 35 & $\begin{array}{l}\text { Bulamare, Sabare, Tongare } \\
46\end{array}$ & Nill \\
\hline Yola South & Nill & Yola & $\begin{array}{l}\text { Bulamare, } \\
\text { Rumuda Waziri, } \\
\text { Wuro Ardo Kyari }\end{array}$ & $\begin{array}{l}\text { Dumayo, Gujibabu, Uki, } \\
\text { Mayo Kohi }\end{array}$ & Nill \\
\hline 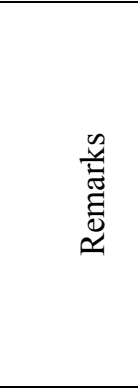 & $\begin{array}{l}\text { Urgent Evacuation } \\
\text { Of The People } \\
\text { During Floods And } \\
\text { Permanent } \\
\text { Relocation Of All } \\
\text { The Villages In } \\
\text { This Zone To } \\
\text { Higher Terrain } \\
\text { Areas }\end{array}$ & $\begin{array}{l}\text { This Zone Is Also } \\
\text { Liable To Floods } \\
\text { Though } \\
\text { Depending On } \\
\text { Rainfall Intensity } \\
\text { And Closeness To } \\
\text { River Benue. } \\
\text { Proper Early } \\
\text { Warning And } \\
\text { Town Planning } \\
\text { Measures Are To } \\
\text { Be Put In Place }\end{array}$ & $\begin{array}{l}\text { Lower Flood Risk } \\
\text { But Areas That } \\
\text { Are Closer To The } \\
\text { Basin Have } \\
\text { Higher } \\
\text { Vulnerability To } \\
\text { Flood Risk. The } \\
\text { Area Can Be Used } \\
\text { For Camps For } \\
\text { Flood Refugees }\end{array}$ & $\begin{array}{l}\text { The Uplands Can Never Be } \\
\text { Affected By The Flood But } \\
\text { Could Serve As Refugee } \\
\text { Ground For The Victims }\end{array}$ & \\
\hline
\end{tabular}




\subsection{Escape Routes and Shelter Sites in the Flood Prone Areas}

The escape routes and shelter areas as shown in Figure 7, are summarized as follows

(i) The black oval-shaped rings on the map show the two places where the roads cross the River Benue from north to south at Numan and at Jimeta-Yola (Figure 7). These two places are therefore, the major escape routes across the river; hence, the rescue team will direct their movements towards these two areas that is, Numan or Jimeta-Yola.

(ii) The victims can also be evacuated to higher elevation areas such as upland and plain areas where there is no flood or where the flood is at minimal. The red arrows on the map (Figure 6) indicate the direction of the victims to saver places.

(iii) Since the generated DEM map was based on height, the Benue plains and the Upland areas are higher grounds where shelter or refugee camps for the victims that are relocated from the Benue Banks, Benue Basin or the buffer zones can be built for the victims.

(iv) The Islands within the River Benue as well as higher elevation areas close to the rivers can serve as

field for helicopters during the search and rescue of the victims by the rescue team

\subsection{Geo-Database and Spatial Query for Decision Making}

The query module of the ArcGIS software was used to analyze the spatial and non-spatial features of the study. For example, assuming the government is interested in the list in alphabetical order of all the communities or villages that are highly vulnerable to flood. From Figure 6, the flood vulnerability of each of the communities can be identified and delineated by using the query module to select the desired communities. That is, all the communities that are located on the River Banks as well as those within the $3 \mathrm{kms}$ buffer zone. A closer look at the location column in the inserted table in Figure 9 revealed that all the highlighted communities on the maps are conspicuously found within the buffer zone which automatically includes those communities that are located on the river banks which are collectively classified as highly vulnerable areas, while those on other terrains like plains, Benue Basin and uplands are not highlighted. The communities, when selected automatically reflect on the map and the database at once as shown in Figure 9.

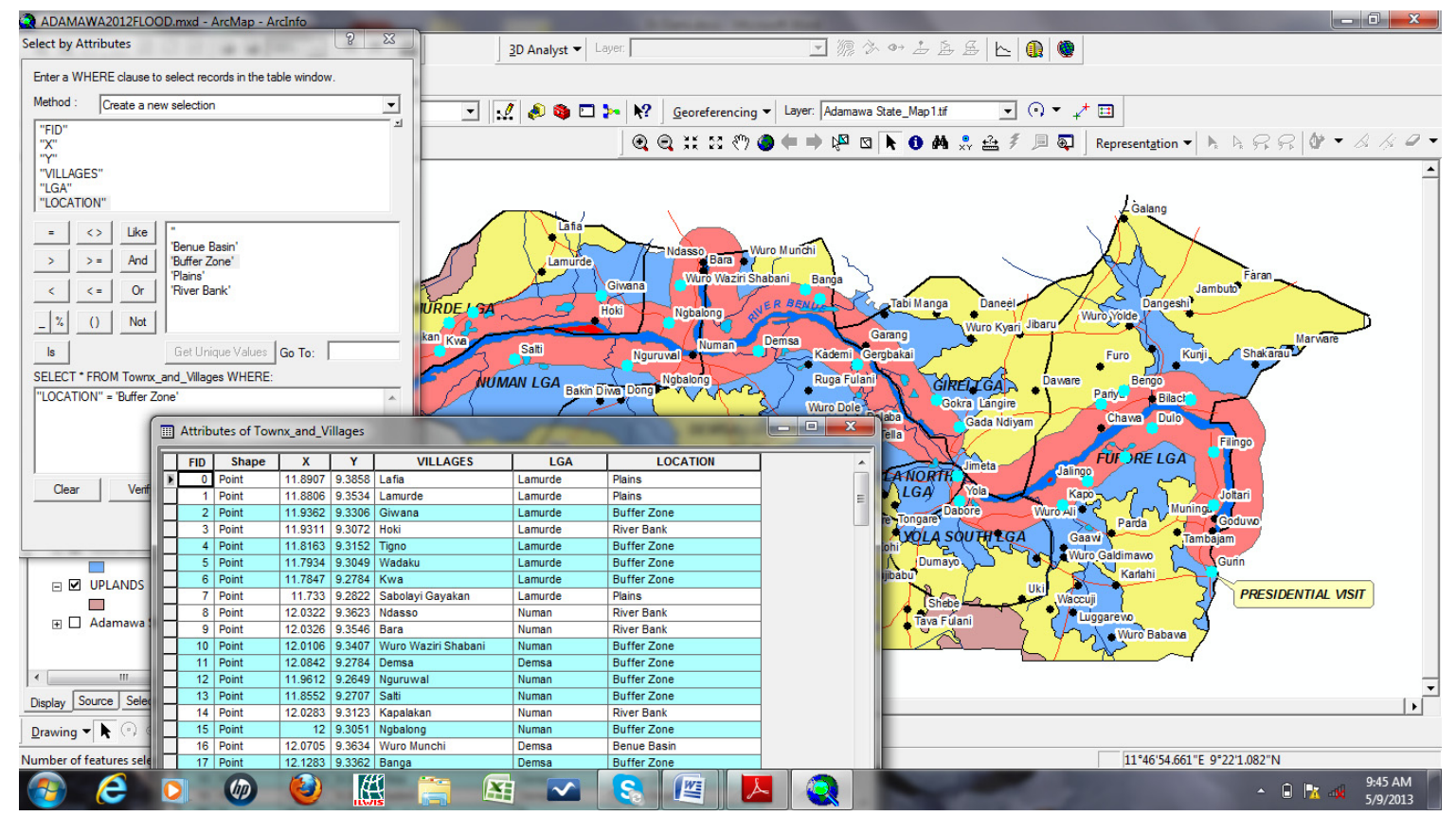

Figure 9. Selection of highly flood vulnerable communities in the Geo-Database

The names of the selected communities are then automatically labeled and alphabetically arranged through the label module of the ArcGIS software. The output map (Figure 9) shows each of the communities as well as their coordinates, the LGAs, and where they are located, (that is, either, on the river banks or within the buffer zone) are shown. Complex operations can also be done from the selected communities. For instance, one can select 
from the selected communities only those from a particular or more than one LGA. Moreover, the use of identify icon on any of the communities automatically gives all the necessary information about the place.

\section{Summary and Conclusions}

The capability of GIS techniques for identification and delineation of communities' vulnerability to floods has been demonstrated in this paper. Vulnerability was classified into four, the highly vulnerable, vulnerable, the marginally vulnerable and the not vulnerable communities. It was revealed that, all the 120 communities in the study were found to be vulnerable to floods. That is, 29 communities $(32.5 \%)$ of the communities were found to be located on highly vulnerable areas, while 35 communities (representing 29.17\%) were found to be located within the vulnerable areas. And the remaining 45 communities (38.33\%) were located on marginally vulnerable areas. All the 29 communities (Table 1) that were found to be highly vulnerable were suggested to be urgently relocated to higher grounds to prevent future occurrences while proper early warning and effective town planning measures should be put in place in those communities that are vulnerable or marginally vulnerable to floods, that is, the 35 and 46 communities that were located on Benue Basin and Plains respectively. Escape routes and shelter sites were also identified in the study. It was revealed that only two bridges (one at Jimeta Yola and the other at Numan) were constructed on River Benue: in Adamawa State. The bridges could serve as escape routes across the river to either the south or towards the north. The higher elevation areas, that is, the plains and upland areas which are less vulnerable to floods and which may also serve as good site for refugee camps were identified and delineated. Database for the vulnerability of the communities in the State was created while spatial queries were used to demonstrate the classification of the vulnerability of the communities to the appropriate classes and selection of desired information for decision making.

\section{Recommendations}

There is the urgent need to revisit the construction of a dam at the upstream of River Benue to hold back waters that are annually released at Lagdo dam as reported by Adamawa State Government (2012) that the annual large scale flooding experienced in Nigeria following the release of water from the Lagdo Dam in Cameroon could have been curbed some 30 years ago if the country had honoured an agreement involving Nigeria and Cameroon in 1980 that the Nigerian government should construct another dam at Dasin village along the course of River Benue in Fufore LGA, Adamawa State, Nigeria. All the 29 communities (Table 1) that were found to be highly vulnerable to floods are recommended to be urgently relocated to higher grounds to prevent future occurrences. The 35 communities that are marginally vulnerable to flood (Table 1) are recommended to be subjected to proper early warning, while effective town planning measures should be put in place in those communities. The Nigerian governments should honour the 1980 agreement between the country and Cameroon by revisiting the construction of Dasin Hausa Dam in Fufore LGA of Adamawa state to contain the gushing water released upstream from Lagdo Dam and curb annual flooding and attendant destruction of property and loss of lives. All the government, private and non-governmental organizations that are involved in flood monitoring and management should imbibe the use of GIS for data generation and decision making so as to minimize the problems of human interventions in major decision makings. This entails that the staff of such organizations should have be well trained in the use of GIS for data generation and decision making. In conclusion, there is the need to prepare against future occurrence of floods in the country bearing in mind that floods does not discriminate, it only marginalizes whomever fails to prepare for it.

\section{References}

Adamawa State Government. (2012). The 2012 Flood Report. Adamawa State: Ministry of Environment.

Adebayo, A. A. (1999). Climate of Adamawa State. In A. A. Adebayo \& A. L. Tukur (Eds.), Adamawa State in Maps. Yola: Paraclette Publishers.

Adebayo, A. A., \& Umar, A. S. (1999): Hydrology and Water Resources of Adamawa State. In A. A. Adebayo \& A. L. Tukur (Eds.), Adamawa State in Maps. Yola: Paraclette Publishers.

Aronoff, S. (1989). Geographic Information Systems: A Management Perspective (p. 53). Ottawa: WDL Publications.

Deckers, P., Kellens, W., Reyns, J., Vanneuville, W., \& De Maeyer, P. (2010). A GIS for flood risk management in Flanders. In Geospatial techniques in urban hazard and disaster analysis (pp. 51-69). Springer Netherlands.

Federal Ministry of Environment, Nigeria: Flood Early Warning Center. (2012). Federal Republic of Nigeria Official Gazette: 2nd February, 2009. Vol. 96 Legal Notice on Publication 2006 Census Final Results. 
Ikusemoran, M. (2000). Remote Sensing and GIS for Flood Surveillance: A Case Study of Kainji Lake Basin, New Bussa, Nigeria. (An Unpublished M., Tech Thesis). Department of Geography, Federal University of Technology, Minna.

Konwea Anthony Chuka. (2012). The Great Nigerian 2012 Flood: Part 1. Retrieved from Think Africa Press: editor@thinkafricapress.com

Ministry of Environment. (2012). Flood Early Warning: June, 2012. Early Warning Center.

Nwilo, P. C., Olayinka, N. D., Ayila, D., \& Adzandar. (2012). Flood Modeling and Vulnerability Assessment of Settlements in the Floodplains Using GIS and Cellular Framework Approach. Global Journal of Human Social Sciences, 12(3).

Nyerges, T. L. (1992, August). Coupling GIS and spatial analytic models. In Proceedings of the 5th international symposium on spatial data handling (Vol. 2, pp. 534-543).

Opeloye, S. A., \& Dio, C. J. (1999). Geology and Mineral Resources of Adamawa State. In A. A. Adebayo \& A. L. Tukur (Eds.), Adamawa State in Maps. Yola: Paraclette Publishers.

The Guardian. (2012). Adamawa Flood: Death Toll Rises to 43, Victims Recount Losses, Fear of Epidemics Looms.

Tukur, A. L. (1999). Landforms of Adamawa State. In A. A. Adebayo, \& A. L. Tukur (Eds.), Adamawa State in Maps. Yola: Paraclette Publishers.

Vanneuville, W., Kellens, W., De Maeyer, P., Reniers, G., \& Witlox, F. (2011). Is' flood risk management'identical to'flood disaster management'? Earthzine.

\section{Copyrights}

Copyright for this article is retained by the author(s), with first publication rights granted to the journal.

This is an open-access article distributed under the terms and conditions of the Creative Commons Attribution license (http://creativecommons.org/licenses/by/3.0/). 